\title{
Developments in The EU-German Judicial Love Story: The Right To Be Forgotten II
}

\author{
Ana Bobić* (1) \\ (Received 23 February 2020; accepted 24 February 2020)
}

\begin{abstract}
The relationship between the Court of Justice and the Bundesverfassungsgericht is perhaps one of the most explored relationships in all of EU's legal history. In attempting to understand and operationalize the uncertainty surrounding the positioning between $\mathrm{EU}$ and national constitutional orders, they have in some respects followed the footsteps of a typical life-long love story: in the early years of European integration, both courts appeared to be in denial of any romance, and entered into a conflict over the question of the final arbiter; they subsequently turned to flirting by moving away from an institutionally based conflict towards finding a common substantive ground; which resulted in finally abandoning the competition for domination, but rather embracing mutual respect and a heterarchical relationship. This brief piece follows these developments in fundamental rights review that for now end with the second German decision concerning the right to be forgotten.
\end{abstract}

Keywords: constitutional review; fundamental rights review; judicial interactions in the EU; EU constitutional law; comparative constitutional law

The relationship between the Court of Justice and the Bundesverfassungsgericht is perhaps one of the most explored relationships in all of EU's legal history. ${ }^{1}$ In attempting to understand and operationalize the uncertainty surrounding the positioning between EU and national constitutional orders, they have in some respects followed the footsteps of a typical life-long love story: in the early years of European integration, both courts appeared to be in denial of any romance, and entered into a conflict over the question of the final arbiter; they subsequently turned to flirting by moving away from an institutionally based conflict towards finding a common substantive ground; which resulted in finally abandoning the competition for domination, but rather embracing mutual respect and a heterarchical relationship. This brief piece follows these developments in fundamental rights review that for now end with the second German decision concerning the right to be forgotten.

\footnotetext{
${ }^{*}$ DPhil (Oxon), Hertie School of Governance, Berlin.

${ }^{1}$ To name a few: Neil MacCormick, The Maastricht Urteil: Sovereignty Now, 1 Eur. L.J. 259 (1995); Mattias Kumm, Who is the final arbiter of constitutionality in Europe: Three conceptions of the relationship between the German Federal Constitutional Court and the European Court of Justice, 36 C.M.L. REv. 351 (1999); Gunnar Beck, The Lisbon judgment of the German Constitutional Court, the primacy of EU law and the problem of Kompetenz-Kompetenz: a conflict between right and right in which there is no Praetor, 17 EUR. L.J. 470 (2011); Editorial Comment Ultra vires - has the Bundesverfassungsgericht shown its teeth?, 50 C.M.L. REv. 925 (2013); Michelle Everson, An exercise in legal honesty: rewriting the Court of Justice and the Bundesverfassungsgericht, 21 EuR. L.J. 474 (2015).
}

( $)$ The Author(s) 2020. Published by Cambridge University Press on behalf of the German Law Journal. This is an Open Access article, distributed under the terms of the Creative Commons Attribution licence (http://creativecommons.org/licenses/by/4.0/), which permits unrestricted re-use, distribution, and reproduction in any medium, provided the original work is properly cited. 


\section{A. The Early Years: A Brief Outline of Institutional Competition}

The early days of European integration were marked by an uncertainty as to the relationship between EU law and national constitutions. There are two specific dynamics driving this ambiguity: First, the principles of direct effect and primacy called into question the previously undisputed supremacy of national constitutions in the national hierarchy of legal norms; and, second, these same principles combined with the preliminary reference procedure undermined the position and influence of national courts entrusted with safeguarding the constitution and its supremacy. Yet, there never was a treaty provision expressly underlining the hierarchical supremacy of EU law over national law. It was therefore left to the Court of Justice and the Bundesverfassungsgericht to use constitutional interpretation to define and protect the positions in their respective legal orders.

An example which begins this power struggle is the German EEC Regulations Constitutionality decision. ${ }^{2}$ The Bundesverfassungsgericht was to decide on a constitutional complaint against two regulations which allegedly breached fundamental rights protected by the Basic Law. The decision was praised by the academic community as Euro-friendly, as the Bundesverfassungsgericht rejected the jurisdiction to review the constitutionality of regulations, due to the autonomous status of the EU's legal order. ${ }^{3}$ Nevertheless, the Bundesverfassungsgericht reserved for itself the power to review EU law should it breach fundamental rights enshrined in the Basic Law.

This decision marks the beginning of a competitive relationship between the two courts, each attempting to reach and stay on top of the judicial hierarchy in the European judicial space. This competition caused the Court of Justice to protect its autonomy and offer its own contribution to the fundamental rights protection landscape. ${ }^{4}$ According to Mancini, it was the "brutal blow's of the above EEC Regulations Constitutionality decision that provoked the Court of Justice to address fundamental rights protection.

The story begins with the well-known Stauder decision: ${ }^{6} \mathrm{Mr}$ Stauder claimed that the Commission's welfare scheme issuing coupons for a subsidized butter price that included his name breached his fundamental right to human dignity. National fundamental rights were, it was long decided, not the acceptable standard of review of EU action. ${ }^{7}$ Unlike the European Convention of Human Rights which acts as the floor for the level of protection, the Court of Justice could not allow national standards to have a role in review and interpretation of EU law, given that its role is to achieve and maintain the uniformity and effectiveness of EU law. Nevertheless, the Court of Justice found a relatively easy way out of this situation, finding that only the German version of the Commission's decision indicated the name as an identifier on the subsidies coupon, thus allowing the German authorities to employ other methods of identification. ${ }^{8}$ More importantly, ${ }^{9}$ the Court stated that ' $[\mathrm{i}]$ nterpreted in this way, the provision at issue contains nothing capable of prejudicing

\footnotetext{
${ }^{2}$ BVerfG, Case EEC Regulations Constitutionality, decision of Oct. 18, 1967, 22 BVerfGE 293.

${ }^{3}$ Monica Claes, The National Courts' Mandate in the European Constitution 597-598 (2006).

${ }^{4}$ Frank Schimmelfennig, Competition and community: constitutional courts, rhetorical action, and the institutionalisation of human rights in the European Union, 13 JEPP 1247, 1248 (2006). See also Heidi Kaila, The scope of application of the Charter of Fundamental Rights of the European Union in the Member States, in CONSTITUTIONALISING THE EU JUDICIAL SYSTEM. EsSAYS In Honour of Pernilla Lindh 292 (P Cardonnel \& A Rosas eds. 2012); Jason Coppel \& Aidan O’Neill, The European Court of Justice: taking rights seriously?, 12 LEGAL STUDIES 227, 229 (1992). For a critique of the latter, see Joseph H. H. Weiler \& N. J. S. Lockhart, 'Taking rights seriously' seriously: the European Court and its fundamental rights jurisprudence - Part I, 32 C.M.L. REv. 51 (1995).

${ }^{5}$ G. Federico Mancini, The making of a constitution for Europe, 26 C.M.L. REV. 595, 609-610 (1989).

${ }^{6}$ CJEU, Case 29/69 Stauder [1969] ECLI:EU:C:1969:57. For an analysis, see Nial Fennelly, Pillar talk: fundamental rights protection in the European Union, 8 Judicial STUdiEs Institute JOURNAL 95, 98 (2008).

${ }^{7}$ CJEU, Case 1/58 Stork [1959] ECLI:EU:C:1959:4, para. 4(a).

${ }^{8}$ Court of Justice Case 29/69 Stauder, supra note 6, at para. 2 .

${ }^{9}$ More importantly is used here as a reference to the consequence, since the Court of Justice only mentions fundamental rights at the end of the judgment, 'in passing', to borrow the phrasing from Coppel \& O'Neill, supra note 4, at 228.
} 
the fundamental human rights enshrined in the general principles of Community law and protected by the Court. ${ }^{\prime 10}$ The Court employed the same technique as regards the expansion of general principles of EU law, by solely giving expression to a pre-existing state of affairs. ${ }^{11}$

A year after, the Court of Justice expanded, or 'revealed', the scope of fundamental rights protection. In Internationale Handelsgesellschaft, ${ }^{12}$ the Administrative Court of Frankfurtam-Main was in doubt as to the compatibility of a regulation concerning export licenses with principles of freedom of action and disposition, of economic liberty, and of proportionality. Again, repeating that national law cannot be the standard of review of EU acts, the Court of Justice provided an autonomous definition of its fundamental rights catalogue:

In fact, respect for fundamental rights forms an integral part of the general principles of law protected by the Court of Justice. The protection of such rights, whilst inspired by the constitutional traditions common to the Member States, must be ensured within the framework of the structure and objectives of the Community. ${ }^{13}$

General principles of law, thus, materially comprised of common constitutional traditions of Member States. While a single national standard was a threat to the primacy, uniformity and effectiveness of EU law, ${ }^{14}$ it was impossible to ignore national constitutional standards of protection of fundamental rights altogether. In the structure of constitutional pluralism, national and EU law are inherently intertwined, thereby ensuring that cross-fertilization is a two-way process of interaction between national and EU constitutional orders. ${ }^{15}$ Still, it is the Court of Justice claiming the ultimate say when it comes to fundamental rights review of EU action.

After the case returned to the Administrative Court, which was not satisfied with the finding of the Court of Justice as regards the status of fundamental rights protection, ${ }^{16}$ it referred the case to the Bundesverfassungsgericht, resulting in the famous Solange I decision. ${ }^{17}$ The decision requires an analysis from the perspective of constitutional pluralism, regardless of the fact the theory has developed and is mostly connected to the much later Maastricht judgment of the Bundesverfassungsgericht. ${ }^{18}$ The Bundesverfassungsgericht first addressed the nature of the EU legal system: 'Community law is neither a component part of the national legal system nor international law, but forms an independent system of law flowing from an autonomous legal source. ${ }^{19}$ The sui generis approach may not be considered

\footnotetext{
${ }^{10}$ CJEU, Case 29/69 Stauder, supra note 6, at para. 7.

${ }^{11}$ Mazák and Moser provide a nice comparison to the Court's 'recognition' of the pre-existing general principles, as opposed to their establishment: Michelangelo's alleged explanation of the statue of David was that he was not created from stone, but rather, Michelangelo saw him in it and removed the unnecessary parts of the stone for David to emerge in his full beauty. Ján Mazák \& Martin K. Moser, Adjudication by reference to general principles of EU law: a second look at the Mangold case law, in Judging Europe's Judges. The Legitimacy of the CASE LAW of THE European Court of Justice 61 (M. Adams et al. eds. 2015).

${ }^{12}$ CJEU, Case 11/70 Internationale Handelsgesellschaft [1970] ECLI:EU:C:1970:114.

${ }^{13} I d$. at para. 4.

14"According to the evaluation of the Verwaltungsgericht, the system of deposits is contrary to certain structural principles of national constitutional law which must be protected within the framework of Community law, with the result that the primacy of supranational law must yield before the principles of the German Basic Law." CJEU Case 11/70 Internationale Handelsgesellschaft, supra note 12, at para. 2.

${ }^{15}$ To use the phrasing of Thym, these orders are 'separate, but not separable.' Daniel Thym, Separation versus fusion - or: how to accommodate national autonomy and the Charter? Diverging visions of the German Constitutional Court and the European Court of Justice, 9 EuCONST 391, 410 (2013).

${ }^{16}$ The intricacies of the exchange between courts was described in detail in Claes, supra note 3, at 599.

${ }^{17} \mathrm{BVerfG}$, Internationale Handelsgesellschaft (Solange I), judgment of May 29, 1974, 37 BVerfGE 271, 2 C.M.L.R. 540 (1974).

${ }^{18}$ MacCormick, supra note 1.

${ }^{19} \mathrm{BVerfG}$, Solange I, supra note 17 , at para. 19.
} 
as a particularly advanced way of defining the nature of the EU's legal order, ${ }^{20}$ but the Bundesverfassungsgericht continues: ' $\mathrm{i}$ ] t follows from this that, in principle, the two legal spheres stand independent of and side by side one another in their validity. ${ }^{21}$ This may in fact be the first expression of the existence of multiple claims to ultimate authority, the first premise of constitutional pluralism. This opens up space for institutional competition, and the two courts are still vying for the winning position. The Bundesverfassungsgericht goes further, and addresses the situation of a possible conflict in the spirit of constitutional pluralism:

This does not lead to any difficulties as long as the two systems of law do not come into conflict with one another in their substance. There therefore grows forth from the special relationship which has arisen between the Community and its members by the establishment of the Community first and foremost the duty for the competent organs, in particular for the two courts charged with reviewing law - the European Court of Justice and the Bundesverfassungsgerichtto concern themselves in their decisions with the concordance of the two systems of law. ${ }^{22}$

The incremental functioning of constitutional pluralism is visible from the joint obligation on behalf of the two courts to accommodate each other's claims to ultimate authority in their respective areas of jurisdiction. The Bundesverfassungsgericht continued by stating that even an exceptional disapplication of a Community or a German obligation would not bring into question the validity of claims of those two legal orders. ${ }^{23}$ The emergence of any possible conflict does not lead to a violation of the Treaty, nor of the Basic Law. ${ }^{24}$ In addition, a possibility of an exceptional 'victory' of one legal order over the other, and vice versa, is in line with the definition of heterarchy, a system in which there is no single winner, but one where participants can be positioned differently in relation to one another at different times.

The remainder of the judgment is widely known: the Bundesverfassungsgericht stated that the Community at that time did not have a catalogue of protecting fundamental rights, ${ }^{25}$ and the conflict should be resolved as follows:

Provisionally, therefore, in the hypothetical case of a conflict between Community law and a part of national constitutional law or, more precisely, of the guarantees of fundamental rights in the Constitution, there arises the question of which system of law takes precedence, that is, ousts the other. In this conflict of norms, the guarantee of fundamental rights in the Constitution prevails as long as the competent organs of the Community have not removed the conflict of norms in accordance with the Treaty mechanism. ${ }^{26}$

\section{B. Exploring a Substantive Common Ground}

The German Solange II decision ${ }^{27}$ more closely resembles the controlimiti approach of the Italian Constitutional Court, ${ }^{28}$ rather than its own position in Solange I, and more generally follows the framework of constitutional pluralism. First, the Bundesverfassungsgericht called the Court of

\footnotetext{
${ }^{20}$ Federico Fabbrini, Fundamental Rights in Europe. Challenges and Transformations in Comparative Perspective 23 (2014).

${ }^{21}$ BVerfG, Solange I, supra note 17 , at para. 20.

${ }^{22} I d$.

${ }^{23} I d$. at para. 21 .

${ }^{24} I$ d.

${ }^{25}$ Although it did not rule out the possibility this might change. BVerfG, Solange I, supra note 17, at para. 23.

${ }^{26} I d$. at para. 24 .

${ }^{27}$ BVerfG, Solange II, docket no. 2 BvR 197/83, decision of Oct. 22, 1986, 3 C.M.L.R. 225 (1987).

${ }^{28}$ According to which it retains for itself the right to an ultimate say in fundamental rights protection solely in the event of a violation of the fundamental principles of the Italian constitutional order or the inalienable rights of man. Corte costituzionale, Frontini, docket no. Case 183/73, decision of Dec. 27, 1973, 2 C.M.L.R. 372 (1974), para. 12.
} 
Justice 'a sovereign organ of judicature', that has the 'judicial monopoly' as regards the interpretation and validity of EU law, ${ }^{29}$ acknowledging multiple claims to ultimate authority in overlapping areas of jurisdiction. The Bundesverfassungsgericht proceeded:

That partly functional incorporation of the European Court into the jurisdictions of memberStates expresses the fact that the legal orders of member-States and that of the Community are not abruptly juxtaposed in a state of mutual insulation but are in numerous ways related to each other, interconnected and open to reciprocal effects. ${ }^{30}$

Solange II thus marks the end of the initial period of a more institutionally-based constitutional conflict in the European Union, settling the question of whether the Court of Justice has jurisdiction in the area of fundamental rights. The conflict opened the door for a more substanceoriented discussion between the two courts, in relation to the proper standard of fundamental rights protection.

Having established a catalogue of fundamental rights protection for matters of EU law, ultimately expanding the self-referential system of the Treaties, ${ }^{31}$ the Court of Justice proceeded by attempting to establish itself as the constitutional court of the European Union. ${ }^{32}$ For this purpose, it extended its jurisdiction of fundamental rights review in relation to review of national measures ${ }^{33}$ which, according to Lenaerts, was important in terms of providing reassurance to national (constitutional) courts that the basic values of their constitutions are adhered to. ${ }^{34}$ Further, the Court set out a wide interpretation of the scope of the Charter of Fundamental Rights in Fransson. ${ }^{35}$ It interpreted the wording of Article 51(1) of the Charter, which confines the Charter's scope to situations when Member States are "implementing Union law", to mean all situations when the national legislation "falls within the scope of European Union law". In conclusion on the substance of fundamental rights protection at the EU level, it is necessary to add also the Melloni decision, where the Court of Justice stated that the Charter provide for a satisfactory level of protection of fundamental rights, even when a higher standard of protection is prescribed by a national constitution. ${ }^{36}$

From the perspective of the Bundesverfassungsgericht, the Banana Market Regulation deci$\operatorname{sion}^{37}$ needs to be mentioned, and how it shaped the fundamental rights review under the Basic Law. The decision came after an almost decade long saga ${ }^{38}$ initiated by the Council

\footnotetext{
${ }^{29} \mathrm{BVerfG}$, Solange II, supra note 27 , at paras. $4,6$.

${ }^{30} I d$. at para. 7.

${ }^{31}$ The protection of fundamental rights first entered the text of the Treaties in the Preamble to the Single European Act (1987) and in Article F of the Maastricht Treaty (1992).

${ }^{32}$ John J. Barceló III, ECJ review of Member State measures for compliance with fundamental rights, Cornell Law School Legal Studies Research Paper No. 10-001 (2009), <http://scholarship.law.cornell.edu/cgi/viewcontent.cgi? article $=1096 \&$ context $=$ clsops_papers $>$, 4; STEPHEN WEATHERILL, LAW AND VALUES IN THE EUROPEAN UNION 152 (2016). For a recent argument on the existence of supranational constitutional courts, see Federico Fabbrini \& Miguel P. Maduro, Supranational constitutional courts, iCourts Working Paper Series No. 98 (2017), <https:// papers.ssrn.com/sol3/papers.cfm?abstract_id=2990277>.

${ }^{33}$ CJEU, Case C-260/89 ERT [1991] ECLI:EU:C:1991:254, para. 43. The Court of Justice confirmed in later cases that this relates to implementing all sources of EU law. See CJEU, Case C-309/96 Annibaldi [1997] ECLI:EU:C:1997:631, paras. 14 to 21; CJEU, Case C-384/05 Piek [2007] ECLI:EU:C:2007:21, para. 34. The Court of Justice confirmed explicitly that this also entails situations where the Member States have a wide discretion in the implementation obligation. CJEU, Case C-292/97 Karlsson [2000] ECLI:EU:C:2000:202, para. 35.

${ }^{34}$ Koen Lenaerts, The Court of Justice of the European Union and the Protection of Fundamental Rights, 31 POLISH YEARBOOK OF INT. L. 79, 89 (2011).

${ }^{35}$ CJEU, Case C-617/10 Fransson [2013] ECLI:EU:C:2013:105, para. 21.

${ }^{36}$ CJEU, Case C-399/11 Melloni [2013] ECLI:EU:C:2013:107, paras. 55 to 61.

${ }^{37}$ BVerfG, Banana Market Regulation, docket no. 2 BvL 1/97, Order of June 7, 2000.

${ }^{38}$ For a more detailed analysis of the intricacies of the case, see Christoph U. Schmid, All bark and no bite: notes on the Federal Constitutional Court's “Banana Decision", 7 Eur. L. J. 95 (2001); ClAES, supra note 3, at 610-620.
} 
Regulation regulating the market in bananas. ${ }^{39}$ Three challenges before the Court of Justice ${ }^{40}$ were unsuccessful, and the Administrative Court of Frankfurt-am-Main ultimately submitted a reference to the Bundesverfassungsgericht. ${ }^{41}$ In finding the reference inadmissible, the Bundesverfassungsgericht outlined its approach towards the review of secondary EU law:

[Constitutional] review under Article 100(1) GG which refer to rules that are part of secondary European Community law [is] only admissible if [its] grounds show in detail that the present evolution of law concerning the protection of fundamental rights in European Community law, especially in case law of the Court of Justice of the European Communities, does not generally ensure the protection of fundamental rights required unconditionally in the respective case. ${ }^{42}$

Reiterating its Solange and Maastricht jurisprudence, the conditions for activating fundamental rights review by the Bundesverfassungsgericht were as follows:

The constitutional requirements are satisfied [...] if the rulings of the Court of Justice [...] generally ensure effective protection of fundamental rights as against the sovereign powers of the Communities which is to be regarded as substantially similar to the protection of fundamental rights required unconditionally by the Basic Law, and in so far as they generally safeguard the essential content of fundamental rights. ${ }^{43}$

The judgment was criticized for its leniency and lack of engagement with actual infringements of the fundamental rights at stake, ${ }^{44}$ and for abandoning its cooperative relationship with the Court of Justice in fundamental rights review as set out in its Maastricht decision. ${ }^{45}$ What can be concluded for the purposes of the present discussion is that the Bundesverfassungsgericht will apply self-restraint in fundamental rights review, reviewing only manifest violations ${ }^{46}$ of fundamental rights. ${ }^{47}$

\footnotetext{
${ }^{39}$ Council Regulation 404/93 of 13 February 1993 on the common organization of the market in bananas [1993] OJ L47/1. Challenges against the Banana Regulation were brought before national constitutional courts, the Court of Justice and the Dispute Settlement Body of the WTO, see Schmid, supra note 38, at 96. These procedures will not be analyzed as they are of no relevance for the present discussion.

${ }^{40}$ CJEU, Case C-280/93 Federal Republic of Germany v Council of the European Union [1994] ECLI:EU:C:1994:367; Case C-466/93 Atlanta [1995] ECLI:EU:C:1995:370; Case C-68/95 T Port [1996] ECLI:EU:C:1996:452.

${ }^{41}$ This was the third instance that the Bundesverfassungsgericht decided on the same regulation. For more information, see ClaEs, supra note 3, at 616.

${ }^{42} \mathrm{BVerfG}$, Banana Market Regulation, supra note 37 , at para. 31.

${ }^{43} I d$. at para. 38 .

${ }^{44}$ Schmid, supra note 38 , at 100.

${ }^{45}$ Id. Miriam Aziz, Sovereignty Lost Sovereignty Regained - Some Reflections on the Bundesverfassungsgericht's Bananas Judgment, 9 Col. J. Eur. L. 109, 124 (2002); Donald P. Kommers \& Russell A. Miller, The Constitutional Jurisprudence of the Federal Republic of Germany 340 (3rd ed. 2012).

${ }^{46} \mathrm{I}$ am intentionally using the Honeywell language in this context, which was equally criticized for its unattainable threshold. For criticism directly concerning this similarity, see Christoph Möllers, German Federal Constitutional Court: Constitutional Ultra Vires Review of European Acts Only Under Exceptional Circumstances; Decision of 6 July 2010, 2 BvR 2661/06, Honeywell, 7 EuConst 161, 161 (2011).

${ }^{47} \mathrm{An}$ argument that I have not come across in the literature is a connection between the German initiative and role in the process of creating the Charter of Fundamental Rights, which began in 1999 during the German Presidency, and the more restrained approach of the Bundesverfassungsgericht a year later. After all, the lack of a binding catalogue of fundamental rights at the EU level was one of the main criticisms directed to the EU in the Solange I decision. In that sense, we may read the approach of the Bundesverfassungsgericht in the Bananas Market Regulation decision as one of endorsing a satisfactory progress that European integration has made in the area of fundamental rights protection. The pluralist constellation presupposes a dynamic development of the law through a constructive discussion across the jurisprudence of constitutional conflict (the auto-correct function of constitutional pluralism). Fundamental rights protection is but one example. See Ana Bobić, Constitutional pluralism is not dead: An analysis of interactions between the European Court of Justice and constitutional courts of Member States, 18 GER. L.J. 1395 (2017).
} 
The final decision to be mentioned in this section concerned a case where the Bundesverfassungsgericht was asked to review an execution of the EAW, concerned with the protection of the principle of individual guilt in opposition to the execution of the EAW based on a trial in absentia. The Düsseldorf Higher Regional Court allowed the extradition of a person sentenced in absentia in line with the EAW Framework Decision, who then submitted a constitutional complaint. Although the threshold for fundamental rights review from its Bananas Market Regulation had not been met, the Bundesverfassungsgericht found that when the fundamental right in question is part of human dignity, which is part of the German constitutional identity, it will nevertheless carry out the review. ${ }^{48}$ The Bundesverfassungsgericht found that the right to a fair trial had been breached, and quashed the decision of the Higher Regional Court, without submitting a preliminary reference to the Court of Justice. ${ }^{49}$ In its reasoning, the Bundesverfassungsgericht engaged with the decision of the Court of Justice in Melloni and the limits the latter imposed on the refusal to execute an EAW in the name of effectiveness, uniformity and primacy of EU law. The Court moreover mentioned the exhaustive character of the EAW Framework Decision regarding exceptions to the execution of the EAW in relation to trials in absentia. ${ }^{50}$ It concluded, nevertheless, that 'the principle of mutual trust that governs extraditions within Europe is limited by human dignity guaranteed under Art. 1 sec. 1 [of the Basic Law]'. ${ }^{51}$

It is here that we are seeing clearly the reconciliatory approach between the two bodies of law protecting fundamental rights. Specifically, while EU law more generally protects human dignity to a sufficient degree, it is only in exceptional cases, which do not undermine the validity of EU law, that the Basic Law will take precedence. In the same manner, the application of primacy that exceptionally disapplies a provision of the Basic Law does not render it invalid. Rather, the autocorrect function of constitutional pluralism balances out these respective claims to sovereignty, as they are both accommodated over time.

\section{Entering a New Stage: The Right to Be Forgotten II}

It is at this point that we reach the most recent instance of judicial interactions between the two courts, that in my view reach an important new level: one where the Bundesverfassungsgericht openly disapplies the Basic Law in favor of the EU Charter. ${ }^{52}$ This, according to the German Court, is due to the fact that the right to be forgotten is a matter fully harmonized in Union law. ${ }^{53}$ The judgment emphasizes that the Basic Law may be disapplied due to the context of the case, where the validity or effectiveness of Union law is not in question, but merely its application. ${ }^{54}$ Looking at this decision from the perspective of, for example, the Belgian Constitutional Court, ${ }^{55}$ it would not be as remarkable, given that the latter has since the beginning accepted the authority of the Court of Justice in fundamental rights protection. The Bundesverfassungsgericht has, as described in the previous sections, provided reservations to the influence of Union law on

\footnotetext{
${ }^{48}$ BVerfG, docket no. 2 BvR 2735/14, Order of Dec. 15, 2015, para. 34.

${ }^{49}$ Interestingly, Lenaerts concludes that the Bundesverfassungsgericht 'endorsed the level of fundamental rights protection provided for by the EAW Framework Decision as interpreted by the ECJ in Melloni.' Koen Lenaerts, La Vie Après l'Avis: exploring the principle of mutual (yet not blind) trust, 54 C.M.L. REV. 805, 819 (2017).

${ }^{50}$ BVerfG, supra note 48 , at paras. $79-82$.

${ }^{51} I d$. at 83. For a more detailed analysis, see Julian Nowag, EU law, constitutional identity, and human dignity: a toxic mix? Bundesverfassungsgericht: Mr R 2 BvR 2735/14, Mr R v. Order of the Oberlandesgericht Düsseldorf, Order of the Bundesverfassungsgericht (Second Senate) of 15 December 2015, DE:BVerfG:2015:rs20151215.2bvr273514, 53 C.M.L. REV. 1441 (2016).

${ }^{52}$ BVerfG, docket no. 1 BvR 276/17, decision of Nov. 6, 2019 - Right to be forgotten II, para. 42.

${ }^{53} \mathrm{Id}$.

${ }^{54} I d$. at para. 52.

${ }^{55}$ The Belgian Cour Constitutionnelle is leading in the number of submitted references with 38. CJEU, Annual Report (2018) $<$ https://curia.europa.eu/jcms/upload/docs/application/pdf/2019-04/_ra_2018_en.pdf>, 144.
} 
the Basic Law standards, and has expressed the need to reassure itself that the high standards of fundamental rights protection in the Basic Law are indeed sufficiently protected.

While acknowledging the two systems of fundamental rights protection are different in their validity, and while the reservations from the earlier case law described still remain, ${ }^{56}$ the Bundesverfassungsgericht is keeping in mind the need for a uniform application of harmonized Union law. In that sense, it is monitoring the way that national courts are applying the Charter and whether they are keeping with the obligations stemming therefrom. ${ }^{57}$ There are several questions related to this announcement: (1) is the German interpretation relevant for the other Member States and how they interpret the right to be forgotten?; (2) what is the role of the cross-referencing to other Member States' practice throughout the judgment and would this analysis not necessarily entail an obligation of submitting a preliminary reference to the Court of Justice?

In relation to the first question, the Bundesverfassungsgericht stressed that such uniformity can partially be read from the European Convention on Human Rights, ${ }^{58}$ but it also undertook the analysis of what the requisite standard of protection of fundamental rights in the Charter is in the case at hand. It is also, importantly, acknowledging that hardly any differences remain, as the Basic Law may be presumed to respect the Charter's level of fundamental rights protection. ${ }^{59}$ The interpretation merits citation in full:

Today, the Union's fundamental rights are also part of the protection of fundamental rights that is to be enforced vis-à-vis the German state. In accordance with Article 51.1 of the Basic Law, they are applicable at the national level and constitute a functional equivalent to the fundamental rights of the Basic Law. Embedded in an elaborated catalogue of fundamental rights, they have a function largely identical to that of the German fundamental rights for law under the Basic Law in terms of their content and normative claim for Union law and its interpretation today $[\ldots] .^{60}$

This interpretation alone would lead us to conclude that the standard is to be read analogously to the one enshrined in the Basic Law. However, the German Court makes no reference to the consequences of such a conclusion for the EU-wide application of the Charter. What this means for the future is closely connected to answering the second question posed above.

Secondly, then, the Bundesverfassungsgericht announces that when it applies Union standards of fundamental rights protection, it does so in close cooperation with the Court of Justice. ${ }^{61}$ It, however, interprets this obligation of cooperation as contingent upon the degree of convergence in the legal practice of Member States, importantly, from a systemic perspective, rather than on a case by case basis. ${ }^{62}$ It then undertakes a comparative analysis of the standards of protection provided in the case law of the Court of Justice, as well as national courts of other Member States. The Bundesverfassungsgericht states that Article 267(3) TFEU should be applied in any case when a certain standard of fundamental rights protection sourced in EU law is not sufficiently clear, but in this case undertakes the analysis and concludes, substantively, that it is able to apply clearly the uniform standard applicable to the entire Union. ${ }^{63}$ This practice was already used in the preliminary reference concerning the OMT mechanism, where the German Court cited courts from

\footnotetext{
${ }^{56}$ The standards of the Basic Law remain 'dormant' according to the Bundesverfassungsgericht so long as the EU level of protection is sufficiently effective. BVerfG, supra note 52, at paras. $42,46,47$.

${ }^{57} I d$. at para. 66.

${ }^{58} I d$. at para. 44.

${ }^{59} I d$. at para. 59.

${ }^{60} I d$.

${ }^{61} I d$. at para. 68.

${ }^{62} \mathrm{Id}$. at para. 71.

${ }^{63} I d$. at paras. $137-141$.
} 
eleven different Member States in support of its interpretation of the concept of constitutional identity, although Claes and Reestman found these references to be somewhat misleading. ${ }^{64}$ Whether the Bundesverfassungsgericht used cross-referencing superficially to avoid the preliminary reference procedure, or to connect courts in the EU on a more systemic level, yet remains to be seen. However, the practice of cross-referencing most certainly contributes to a pluralist understanding of judicial interactions in the EU. ${ }^{65}$

Due to the procedural avenue employed in the present case, it is unlikely that this concrete case will reach the Court of Justice by way of a preliminary reference procedure, certainly a preferred route for the Court of Justice. ${ }^{66}$ It could be said that the Court of Justice may see this as a misinterpretation of the CILFIT criteria that need to be met for a national court not to refer a matter of Union law under Article 267 TFEU. ${ }^{67}$ However, as was the case in all previous interactions between the two courts, the Court of Justice will in a later, parallel case, certainly be given an opportunity to express itself upon the interpretation put forward, as well as the procedural solutions chosen by the Bundesverfassungsgericht. It will have two options: the first is to place the preliminary reference procedure at the core of judicial cooperation in the EU, and demand that situations like these pertain in its own exclusive jurisdiction to interpret Union law under Article 19 TEU; the second option will be to disregard the institutional conflict, and side with the substantive level of protection afforded in the case, where the Charter is the sole source of standards of protection to be applied.

Following the logic presented in the introduction, but also through the analysis of the interactions between the two courts throughout the decades of European integration, I am of the view that the Court of Justice will choose the second option, and engage in a substance-oriented cooperation with the Bundesverfassungsgericht in the future.

\footnotetext{
${ }^{64}$ Monica Claes \& Jan-Herman Reestman, The Protection of National Constitutional Identity and the Limits of European Integration at the Occasion of the Gauweiler Case, 16 GER. L.J. 917, 941 et seq. (2015)

${ }^{65}$ Bobić, supra note 47 , at 1420 .

${ }^{66}$ CJEU, Case C-294/83, Les Verts, [1986] ECLI:EU:C:1986:166, at para. 23. See also, Mark Dawson \& Ana Bobić, Quantitative Easing at the Court of Justice - Doing whatever it takes to save the euro: Weiss and Others, 56 C.M.L. REV. 1005, 1038 (2019).

${ }^{67}$ CJEU, Case C-283/81 CILFIT [1982] ECLI:EU:C:1982:335, at 21.
}

Cite this article: Bobić A (2020). Developments in The EU-German Judicial Love Story: The Right To Be Forgotten II. German Law Journal 21, 31-39. https://doi.org/10.1017/glj.2020.15 